\section{Consumer Preference and Willingness to Pay for Azaleas: Effect of State Labeling and Various Types of Retail Outlets}

\author{
Madiha Zaffou \\ Department of Agricultural and Resource Economics, University of \\ Connecticut, Storrs, CT 06259
}

\author{
Benjamin L. Campbell ${ }^{1}$ \\ Department of Agricultural and Applied Economics, University of Georgia, \\ Athens, GA 30602
}

Additional index words. choice experiment, garden center/nursery, green industry, home improvement store/mass merchandiser

\begin{abstract}
Over the last decade, there has been a move by many consumers to purchase locally grown products. Many studies have focused on food with limited studies examining plants. Using an online survey of Connecticut residents in conjunction with a choice experiment, we examine the impact of various attributes (e.g., local labeling, retail outlet, color, bloom, and price) on preference and willingness to pay (WTP) for azaleas. Results of the latent class model $(L C M)$ indicate that only one of the latent classes, $\approx 43 \%$ of the sample, valued local labeling. Furthermore, the same class that valued local also preferred a nursery/greenhouse outlet over a home improvement center/mass merchandiser. Recommendations for the different retail outlets are given based on the results.
\end{abstract}

The market for green industry products, especially plants, has begun to reach maturity which means sales are increasing at a decreasing rate (Hall and Dickson, 2011). As the industry reaches maturity, firms can either take market share from other firms or transition nonbuyers to buyers to increase sales (Behe et al., 2013). As firms struggle to gain/retain market share and bring in new customers, it is essential to evaluate consumer reaction to various marketing activities. Given that many nursery/ greenhouse firms operate on "thin profit margins" (Sturdivant, 2013), it is important to understand how local labeling and the intrinsic value, if any, associated with an outlet type (i.e., home improvement center/mass merchandiser vs. nursery/greenhouse) can impact consumer preference and/or WTP.

Consumer demand for local products has continued to climb over the past decade. Notably, much of the focus has been on food products with recent estimates of local food sales around $\$ 6.1$ billion in 2012, which was an increase of $27 \%$ from 2008 (Low and Vogel, 2011; Low et al., 2015). Studies have shown that many consumers prefer and may be willing to pay a premium for local food

\footnotetext{
Received for publication 4 Apr. 2016. Accepted for publication 8 June 2016.

Funding has been provided by the Specialty Crop Block Grant Program of the Agricultural Marketing Service, U.S. Department of Agriculture, awarded and administered by the Connecticut Department of Agriculture.

${ }^{1}$ Corresponding author. E-mail: bencamp@uga. edu.
}

(Darby et al., 2008; Onozaka and McFadden, 2011; Yue and Tong, 2009). Perceived benefits of locally labeled plants, such as being better for the environment from a production perspective, helping the local economy, and product quality, closely align with perceived benefits of local food (Campbell et al., 2014; Khachatryan and Rihn, 2015). However, little attention has been devoted to evaluating the value of locally grown labeling on plants. The few studies that have examined this topic have shown that local labeling has the potential to generate positive consumer preference and price premiums. For instance, Collart et al. (2010) showed dichotomy in the market with plant brand) willing to pay more, while other consumers (i.e., those not aware of a local plant brand) discounted a local plant brand. Collart et al. (2013) showed that consumers purchasing plants more often are more likely to pay a premium for a local brand. Rihn et al. (2015) found that an in-state (Fresh from Florida) and domestic (grown in the United States) label increased preference for indoor foliage plants. Yue et al. (2011) found that women and certain types of plant buyers value local plants.

The intrinsic value associated with a nursery/greenhouse (home improvement center/mass merchandiser) retail outlet can also be a potentially valuable selling point compared with home improvement center/ mass merchandiser (nursery/greenhouse) retail outlet. However, as with local labeling, there has been limited research examining the value of retail outlet on consumer preference and WTP for plants. Yue and Behe (2008) examined consumer choice of floral some consumers (i.e., those aware of a local retail outlet and found that consumers purchasing foliage and garden plants were more likely to choose a box store. Furthermore, they found that box stores and a general retailer were chosen because of their reputation for convenience and lower prices. Satterthwaite et al. (2006) noted that convenience was the primary reason for shopping at an independent garden center followed by service, quality, and then price. However, chain outlets are primarily shopped at due to convenience and price with quality and service ranked lower on the list of priorities.

This study differs from previous studies in several ways. First, we evaluated local (grown in Connecticut) against a regional state (New Jersey), nonregional state (Washington), United States, and international (Canada) label so as to understand the trade-offs associated with these different labeling schemes. No study could be found in the literature that used specific regional and nonregional states. The use of specific states instead of an aggregate (e.g., regional, domestic) label is an important distinction as most products on the market list, if listed, a specific origin (i.e., producing state) and not a more general origin (e.g., product of United States). Our main hypothesis was that a locally labeled plant would be preferred to a nonlocally labeled plants across all consumer groups given the increasing trend toward purchasing local products. Second, we evaluated the value of retail outlet (nursery/ greenhouse vs. home improvement center/mass merchandiser) to determine if differences exist between different market segments. Our hypothesis was that nursery/greenhouse outlets would be preferred by some, but not all, of the classes.

\section{Materials and Methods}

An online survey was administered in Fall 2012. The survey was focused on Connecticut residents for several reasons, notably due to the funding agency's interest in the Connecticut market. Furthermore, unlike many other states, Connecticut has a strict definition (i.e., produced within the state or 10 miles from point of purchase) around the use of the term local and synonymous terms. Furthermore, the green industry in Connecticut is the largest agricultural sector (compared with all other agricultural production) in both direct sales and economic impact (Lopez et al., 2015). Thereby, increasing the value of this sector could have major implications to the economic climate in the state.

Before initiating the study, the survey and protocols were approved by the requisite internal review board (no. X13-074) at the participating university. Potential respondents were recruited from the database of Global Market Insite, Inc. Potential respondents were contacted via e-mail and asked to participate. Respondents choosing to participate were directed to the study. The only criteria for participating in the survey was to be 18 years or older. We allowed purchasers and nonpurchasers of azaleas (the plant used in the choice experiment) to participate as we 
wanted to see if any preference differences existed between these two groups. The first step of the study involved respondents answering general purchasing questions about plant products. They then proceeded to the choice experiment where they were provided information about how the experiment worked, a reminder they were purchasing only one plant, and a statement about how they should consider their budget constraint when making their purchase decision. After completing the choice experiment, respondents answered typical demographic and socioeconomic questions, such household income, age, number of children in household, gender, and ethnicity.

The completion rate for the survey was $85 \%$ which resulted in 720 completed surveys. With respect to representativeness, significance testing was not feasible since census estimates do not include standard errors. However, our sample tended to be older, have a higher median household income, and was made up of more females than males compared with the average Connecticut resident (Table 1). For comparison, the median age (including minors which does not directly align with our sample of only adults) and household income for Connecticut residents is around 40 years and $\$ 70,000$, respectively (U.S. Census Bureau, 2011, 2015). Exclusion of children would put the Connecticut median age closer to our sample median age. Even though our sample appears to be different from the average Connecticut resident with respect to household income, it is seemingly in-line with a typical green industry consumer which is thought to be older with a higher income (Baldwin, 2015; Butterfield, 2004; Dennis and Behe, 2007).

Product attributes and levels. Azaleas were chosen as the plant used in the experiment after consultation with the Connecticut Department of Agriculture and leading nursery/greenhouse outlets. Specific attributes and attribute levels were identified through discussions with leading nursery/greenhouse outlets and via a review of past literature of consumer plant studies, such as Behe et al. (1999), Palma et al. (2010), and Rihn et al. (2015). A 2-gallon azalea was chosen as the product with price, origin, bloom, location, and color being the key attributes identified as important within the purchase decision (Table 2). The price range was from $\$ 15.99$ to $\$ 27.99$ per plant, while color levels were white, red, pink, and fuchsia. Also of interest was the value of a blooming plant. Discussions with several retailers indicated that consumers often show preference and WTP premiums for plants in-bloom. Thereby, we included the bloom attribute with two levels, in-bloom and not in-bloom.

The final two attributes included were of particular interest to this study. Plants were labeled as either grown in Connecticut, New Jersey, Washington, United States, Canada, or were not labeled. The grown in Connecticut label was the local label (as defined by Connecticut law), while New Jersey represented a state in close proximity to Connecticut, thereby, a plant from New Jersey would be regional in nature. Washington (azaleaproducing state on the West Coast), United States, and Canada served as other potential labels that were found on the market and represented varying geographic distances from Connecticut. We also included a "no label" level whereby no information was given about the production origin. The "no label" is important as many retailers do not label the origin of their plants, so understanding the implication of not labeling is critical. Finally, we indicated that the azaleas were either for sale at a home improvement center/mass merchandiser or nursery/greenhouse. Home improvement centers (e.g., Lowe's and Home Depot) and mass merchandisers (e.g., WalMart and Target) constitute the major competitors to nursery/greenhouse outlets.

Experimental design and analysis. Each respondent was presented with eight choice sets that included three azalea products plus a "none" option. The number of choice sets was determined via optimization of the D-efficiency criterion. The criterion compares design efficiency with an orthogonal balanced design to give optimal designs (Kuhfeld, 2010). Each product within a choice set was in the form of text detailing the prescribed attributes. When a product had a "no label" (e.g., no origin specified), no text was provided to denote it was a "no label" option. Given plant labels in a store setting do not put text when an attribute level is not present, leaving no text for a "no label" should provide the most realistic experience for respondents. An example choice set is provided in Fig. 1.

Table 1. Descriptive statistics for key demographic and behavior variables.

\begin{tabular}{|c|c|c|c|}
\hline \multirow[b]{2}{*}{ Variable } & \multicolumn{2}{|c|}{ Sample } & \multirow{2}{*}{$\frac{\text { Connecticut }}{\text { Mean }}$} \\
\hline & Mean & SD & \\
\hline Experience $(\%)^{\mathrm{z}}$ & 0.43 & 0.43 & - \\
\hline Mean income (\$) & 97,928 & 54,107 & - \\
\hline Median & 95,000 & - & $69,899^{y}$ \\
\hline Mean age (yr) & 50 & 14.4 & - \\
\hline Median & 52 & - & $-\mathrm{y}$ \\
\hline Children per household & 0.22 & 0.51 & $-\mathrm{y}$ \\
\hline Male $(\%)$ & 0.34 & 0.47 & 0.49 \\
\hline Caucasian $(\%)$ & 0.89 & 0.32 & 0.81 \\
\hline Number of respondents & 720 & & \\
\hline Number of observation ( 720 respondents $\times 8$ sets $\times 4$ products) & 23,040 & & \\
\hline
\end{tabular}

${ }^{\mathrm{z}}$ Experience $=1$ implies a respondent purchased a 2 -gallon azalea at least once during the past 2 years. ${ }^{y}$ Median age is not provided as the census reported median age for Connecticut is 41 (U.S. Census Bureau, 2011 ), but this includes persons under 18 years of age. Given participation in the survey was contingent on being older than 18 , comparisons to the overall median age would be inappropriate. The number of children per household in Connecticut could not be found. The number of "own" children was available but this is not a direct comparison as our question was for the number of total children.

Table 2. Attributes (and levels) included in the choice experiment.

\begin{tabular}{|c|c|c|c|c|}
\hline Price $(\$)$ & Origin & Bloom & Location & Color \\
\hline 15.99 & Connecticut & In-bloom & Home improvement center/mass merchandiser & White \\
\hline 18.39 & New Jersey & Not in-bloom & Nursery/greenhouse outlet & Red \\
\hline 20.79 & United States & & & Pink \\
\hline 23.19 & Washington & & & Fuchsia \\
\hline 25.59 & Canada & & & \\
\hline 27.99 & No label & & & \\
\hline
\end{tabular}

Given there is the potential for heterogeconsumer tastes and preferences, 2002; Greene and Hensher, 2003; Kafle et al., is similar to the mixed logit model but relaxes be made about the distribution of parameters exact means to determine the number of classes. Similar to other studies using LCM, (2013) Dekhili et al. (2011) and Lim et al. criteria (BIC) whereby we chose the number of classes that had the lowest BIC. For our

For developing the LCM model, we can think of consumer $i$ 's indirect utility conditional on class $s$ when choosing product $j$ as:

$$
\mathrm{U}_{\frac{i j}{s}}=\mathrm{X}_{j} \beta_{s}+\varepsilon_{i j}
$$
sented by vector $\beta_{s}$ and $\varepsilon_{i j}$ is the independent value distributed Type I extreme probability that consumer $i$ is in class $s$ based on

$$
\text { Probability }_{i s}=\frac{\exp \left(\theta_{s} Z_{i}\right)}{\sum_{s} \exp \left(\theta_{s} Z_{i}\right)}
$$
is a parameter vector that determines the probability of class membership. The probability of individual $i$ choosing product $j$ after being assigned their most probable class can be found via: the requirement that assumptions have to lowest BIC value. 


\section{Assume you are purchasing a 2 gallon azalea, which option would you purchase?}

Nursery greenhouse garden center in bloom pink colored azalea grown in Connecticut for $\$ 20.79$

Home improvement center/mass merchandiser not in bloom red colored azalea grown in Canada for $\$ 15.99$

Home improvement center/mass merchandiser in bloom white colored azalea grown in Washington for $\$ 25.59$

$\times$ None of the above

Fig. 1. Example of choice set seen by survey respondents.

$$
\text { Probability }_{i j \mid s}=\frac{\exp \left(\mu_{s} \mathrm{X}_{j} \beta_{s}\right)}{\sum_{j} \exp \left(\mu_{s} \mathrm{X}_{j} \beta_{s}\right)}
$$

where $\mu_{s}$ is the scale parameter for a class $s$ and is normalized to 1 . The joint probability that consumer $i$ in class $s$ chooses product $j$ is:

$$
\begin{aligned}
\text { Probability }_{i j s}= & \text { Probability }_{i j \mid s} \times \text { Prob }_{i s} \\
= & \frac{\exp \left(\mu_{s} \mathrm{X}_{j} \beta_{s}\right)}{\sum_{j} \exp \left(\mu_{s} \mathrm{X}_{j} \beta_{s}\right)} \\
& \times \frac{\exp \left(\theta_{s} \mathrm{Z}_{i}\right)}{\sum_{s} \exp \left(\theta_{s} \mathrm{Z}_{i}\right)}
\end{aligned}
$$

WTP for each attribute level can then be calculated using the LCM coefficients via Eq. [5]:

$$
\mathrm{WTP}_{j}=-\left(\frac{\beta_{j}}{\beta_{p}}\right)
$$

where $\beta$ is the estimated coefficient for each attribute level $j$ and $p$ is the price attribute. Confidence intervals for WTP estimates were found via the delta method.

\section{Results and Discussion}

Examining Table 3, we see three distinct classes with varying preferences. Notably, we find that each class has a significant coefficient associated with the "none" option. This implies that a respondent experienced a decrease in utility if they chose the "none" option, which implies that most consumers received a positive utility from making a choice other than the "none" option. With respect to price, we found a significant and negative coefficient for all classes. The negative coefficient aligns with economic theory that respondents value a lower price to a higher price. However, class 2 had the smallest price coefficient, which implies that this class was most likely the least price sensitive.

Latent class 1-“price emphasis." Class 1 was made up of consumers that are primarily focused on price in their decision to purchase. On the basis of price being the primary driver and the negative sign associated with the coefficient, this class was termed the "price emphasis" group. Other plant studies have found classes/segments that rely heavily on price in their decision-making process, such as Hall et al. (2010) and Behe et al. (2014). The market share associated with this class $(14 \%)$ is comparable to the $13 \%$ and $16 \%$ reported for price-sensitive segments reported by Hall et al. (2010) and Behe et al. (2014), respectively.
There are several interesting features of the "price emphasis" class that impact marketing recommendations for retailers targeting this group. First, in comparison with the other classes older consumers were more likely to be a part of this class. Given older consumers are more likely to be plant buyers (Baldwin, 2015), it would be easy to recommend that retailers catering to older consumers should make sure their price points attractive to better serve this demographic. However, this class had the smallest market share (14\%) and the lack of significance of the retail outlet variable in the latent model could mean these consumers are transient in where they shop and migrate to where they can get the lowest price. Thereby, a strategy built to attract this customer group focusing only on price may not be the right strategy for firms offering higher service, convenience, quality, etc.

Latent class 2-"local/outlets." A primary focus of class 2 was retail outlet and origin labeling; therefore, we named this class the "local/outlet" class. Notably, we see that the nursery/greenhouse retail outlet is preferred to home improvement centers/mass merchandisers (Table 3). Also, the local (grown in Connecticut) label was preferred to all other labels as well as the no label option. As noted above, the "local/outlet" class was the least price sensitive of all the classes. Considering this class most likely preferred local Connecticut-grown azaleas, retailers may be able to market these plants at higher prices in conjunction with local labeling. Further making this a unique market segment, this class prefers a fuchsia-colored azalea compared with all the other colors. Comparatively, white-colored azaleas were the least preferred color.

Furthermore, the "local/outlet" class had a higher probability of being young, Caucasian, and having purchased an azalea in the last 2 years. The previous experience variable's significance and importance of local labeling align with Yue et al. (2011). Given there is some evidence that Caucasian consumers may be more likely to purchase local produce (Racine et al., 2013), this value of local may translate from food to nonfood items. For instance, supporting the local economy is consistently listed as a major reason for purchasing local (Darby et al., 2008; Food Marketing Institute, 2011; Martinez et al., 2010; Onozaka et al., 2010; Yue and Tong, 2009). This class may perceive purchasing local plants as a means to help support the local economy similar to the effect that is assigned for purchasing local food. Alternatively, the local label may be perceived as an indicator that a plant will be more adaptable to local growing conditions and pest pressures.

Taking the results of class 2 in totality, the recommendations for nursery/greenhouse and home improvement centers/mass merchandisers differ, assuming the results hold outside of azaleas. Nursery/greenhouse retail outlets need to focus on capitalizing on the fact this group values the nursery/ greenhouse shopping environment. By offering nontraditional colors, nursery/greenhouse outlets can directly focus on this consumer group compared with the home improvement center/mass merchandiser, which most likely have a more diverse customer base (e.g., broad mix of class 1, 2, and 3 consumers). This is not to say that other colors should not be offered as there is bound to be overlap between consumers frequenting both home improvement centers/mass merchandisers and nursery/greenhouse outlets, but rather having colors available that may not be available, such as fuchsia, at a home improvement center/mass merchandiser can be a means to differentiate from the home improvement center/mass merchandiser. Nursery/greenhouse outlets should also insure that they promote local azaleas, and most likely other plants, as consumers in this group prefer to buy local plants. However, home improvement centers/mass merchandisers need to overcome the preferential view of nursery/greenhouses by these consumers which may entail promoting local azaleas, and other plants, and working to capture sales when/if a consumer from this group shop at their location.

Latent class 3-"variety consumer." Class 3 had a unique set of purchase drivers so they were termed the "variety consumer" (Table 3). The "variety consumer" valued the pink and fuchsia colors over red but values red over white. This was the only class where consumers have distinct preferences across a broad array of colors. Furthermore, we see that this class preferred plants in-bloom. With respect to retail location, we found that consumers in this class have a negative preference toward purchasing their 2-gallon azalea at a nursery/greenhouse compared with a home improvement center/mass merchandiser. In contrast to our hypothesis about local labeling, we found that class 3 does not prefer a locally (Connecticut grown) labeled azalea over a regional (New Jersey grown), U.S. grown, or international import (Canada) label. This class does valued a Washington label overall other labels, which could be related to this class having the perception that the Washington label provides quality azaleas. However, we do not have high-quality answer as to why the Washington label is preferred. Of particular significance to retailers and marketers, the local label was not preferred over the "no label." Given this class was the most price sensitive, the results align with this class preferring home improvement centers/mass merchandisers and having no preference for locally grown since nursery/greenhouse retail outlets and local products are generally perceived as having higher prices (Safley and Wohlgenant, 1995). 
Age was an indicator of membership in this class. Older consumers were less likely to be a member of this class compared with class 1 . With respect to recommendations for retail outlets, home improvement centers/ mass merchandisers would be advised to target this class as the preferential view of nursery/greenhouse outlets is no longer a barrier. Furthermore, this consumer group is open to wider variety of colors as well as azaleas that are in-bloom. Nursery/greenhouse outlets may be best advised to focus on class 2 as class 3 consumers do not prefer nursery/ greenhouse outlets to home improvement centers/mass merchandisers.

Willingness to pay. As can be seen in Table 4, latent class 1 does not have any significant WTP values. This is not surprising

Table 3. Latent class model results for azaleas in 2-gallon containers.

\begin{tabular}{|c|c|c|c|}
\hline & $\begin{array}{l}\text { Latent class } \\
1 \text { “"price emphasis" } \\
\text { class coefficient (SE) }\end{array}$ & $\begin{array}{c}\text { Latent class } \\
\text { 2-“"local/outlet" } \\
\text { class coefficient (SE) }\end{array}$ & $\begin{array}{l}\text { Latent class } \\
\text { 3-“variety" } \\
\text { class coefficient (SE) }\end{array}$ \\
\hline $\begin{array}{l}\text { Percent share (\%) } \\
\text { Pere }\end{array}$ & 0.14 & 0.43 & 0.43 \\
\hline \multicolumn{4}{|c|}{ Parameter estimates } \\
\hline None option & $-5.796(1.060)^{* * *}$ & $-4.85 * * *$ & $-12.903 * * *$ \\
\hline Price & $-0.367(0.060) * * *$ & $-0.084(0.026)^{* * *}$ & $-0.518(0.067)^{* * *}$ \\
\hline Nursery/greenhouse & $0.034(0.440)$ & $0.604(0.144)^{* * *}$ & $-0.769(0.286)^{* * *}$ \\
\hline Canada & -0.232 & $-1.483(0.309)^{* * *}$ & $0.098(0.425)$ \\
\hline Washington & $0.002(0.610)$ & $-1.335(0.245)^{* * *}$ & $1.675(0.862)^{*}$ \\
\hline United States & $-0.125(0.681)$ & $-0.738(0.216)^{* * *}$ & $0.467(0.497)$ \\
\hline New Jersey & $-0.343(0.610)$ & $-0.851(0.240)^{* * *}$ & $0.368(0.554)$ \\
\hline No label & $-0.192(0.641)$ & $-1.242(0.198)^{* * *}$ & $-0.112(0.492)$ \\
\hline White & $0.083(0.517)$ & $-0.438(0.206)^{* *}$ & $-0.794(0.283)^{* * *}$ \\
\hline Pink & $0.060(0.542)$ & $0.226(0.165)$ & $1.143(0.365)^{* * *}$ \\
\hline Fuchsia & $-0.464(0.517)$ & $0.466(0.168)^{* * *}$ & $1.622(0.656)^{* *}$ \\
\hline In-bloom & $0.602(0.487)$ & $-0.060(0.164)$ & $1.549(0.353)^{* * *}$ \\
\hline \multicolumn{4}{|c|}{ Class probability model } \\
\hline Experience & - & $1.102(0.543)^{* *}$ & $0.853(0.540)$ \\
\hline Income & - & $0.000(0.000)$ & $0.000(0.000)$ \\
\hline Age & - & $-0.047(0.021)^{* *}$ & $-0.058(0.021)^{* *}$ \\
\hline Children & - & $0.120(0.397)$ & $-0.052(0.391)$ \\
\hline Male & - & $-0.229(0.547)$ & $0.750(0.524)$ \\
\hline Caucasian & - & $1.980(0.923)^{* *}$ & $0.415(0.714)$ \\
\hline Constant & - & $0.744(1.292)$ & $2.628(1.136)^{* *}$ \\
\hline Log likelihood & & $-1,320.51$ & \\
\hline $\begin{array}{l}\text { Number of respondents (times } 8 \\
\text { choices for total number } \\
\text { of observations) }\end{array}$ & & 720 & \\
\hline
\end{tabular}

Bayesian information criteria (BIC) values for varying latent classes: $1=5546.4$ (from multinomial model as latent class has two or more classes), $2=3016.2,3=2900.7,4=2917.7$, and $5=2976.4$. The BIC is a set criterion for selecting among different models. In general, a lower BIC indicates a better model.

$*, * *, * * *$ Significant at the $0.1,0.05$, and 0.01 level, respectively. Base categories are: home improvement center/mass merchandiser, Connecticut grown, red color, and not in-bloom.

Table 4. Willingness-to-pay estimates from the latent class model results.

\begin{tabular}{lccc}
\hline & $\begin{array}{c}\text { "Price emphasis" } \\
\text { class coefficient }(\mathrm{CI})\end{array}$ & $\begin{array}{c}\text { "Local/outlet" } \\
\text { class coefficient }(\mathrm{CI})\end{array}$ & $\begin{array}{c}\text { "Variety" } \\
\text { class coefficient }(\mathrm{CI})\end{array}$ \\
\hline Nursery/greenhouse & $0.09(-2.25,2.44)$ & $7.17(0.58,13.76)^{* *}$ & $-1.49(-2.47,-0.51)^{* * *}$ \\
Canada & $-0.63(-3.70,2.44)$ & $-17.60(-33.08,-2.13)^{* *}$ & $0.19(-1.40,1.78)$ \\
Washington & $0.00(-3.25,3.26)$ & $-15.84(-27.56,-4.13)^{* * *}$ & $3.24(0.58,5.89)^{* * *}$ \\
United States & $-0.34(-4.02,3.34)$ & $-8.76(-17.43,-0.09)^{* *}$ & $0.90(-0.86,2.66)$ \\
New Jersey & $-0.93(-4.12,2.25)$ & $-10.11(-19.90,-0.31)^{* *}$ & $0.71(-1.31,2.73)$ \\
No label & $-0.52(-3.96,2.91)$ & $-14.74(-25.09,-4.40)^{* *}$ & $-0.22(-2.11,1.67)$ \\
White & $0.23(-2.53,2.98)$ & $-5.20(-9.94,-0.47)^{* *}$ & $-1.53(-2.54,-0.53)^{* * *}$ \\
Pink & $0.16(-2.73,3.06)$ & $2.68(-1.53,6.89)$ & $2.21(1.13,3.29)^{* * *}$ \\
Fuchsia & $-1.26(-4.08,1.55)$ & $5.53(-0.29,11.36)^{*}$ & $3.13(1.15,5.09)^{* * *}$ \\
In-bloom & $1.64(-0.73,4.01)$ & $-0.71(-4.63,3.20)$ & $2.99(2.11,3.88)^{* * *}$ \\
\hline
\end{tabular}

$\mathrm{CI}=$ confidence interval.

$*, * *, * * *$ Significant at the $0.1,0.05$, and 0.01 levels, respectively.

Base categories are home improvement center/mass merchandiser, Connecticut grown, red color, and not in-bloom. likely to prefer to purchase from a home improvement center/mass merchandiser. The premium associated with in-bloom azaleas could be occurring for a variety of reasons, such as the instant gratification associated with a fully colored plant or it could be due to a consumer believing that the plant is of better quality because of the blooms. Future research should delve further into why exactly some consumers prefer plants in-bloom.

\section{Conclusion}

It is essential for firms to identify their consumer base and work to retain the loyal consumers while capturing new customers from their nonbase group. Firms that can effectively identify their consumer base can then use the results above to develop effective marketing strategies to remain successful. Firms that do not know their consumer base can use the results to make better decisions about how to market their products by having a better understanding of the factors that go into a consumer's decision to purchase.

With respect to our findings, it is clear that the market for azaleas, and most likely plants in general, is filled with heterogeneous consumers. As can be seen by the varying preferences of class 1,2 , and 3 members it is extremely hard to give all consumers everything they want. For instance, the "price emphasis" class only values the price of the azalea but they are indifferent to retail outlet, implying they may drift across outlet types. So attempting to gain these consumers by competing directly on price, especially for nursery/ greenhouse outlets that may have higher costs, is risky as potential revenue may be left on the table if "local/outlet" (class 2) consumers are the primary shoppers at the outlet. However, home improvement centers/mass merchandisers may be better situated if they have a lower cost structure due to their economies of scale and/or size, as they can capitalize on class 1's price sensitivity as well as class 3's preference for their outlet type. For nursery/ greenhouse outlets, insuring that they capture class 2 and take a percentage of consumers from classes 1 and 3 may be the ideal scenario. Notably, nursery/greenhouse outlets may be well advised to focus on local labeling which can gain consumers from class 2 . On the basis of the results of this study, retail outlets can put a variety of marketing strategies in place to capture consumers that may be predisposed to shopping at their store, whether it is a focus on price, product origin, or plant characteristics.

\section{Literature Cited}

Baldwin, I. 2015. National gardening survey highlights need for change in retail industry. Today's Garden Center. 20 Jan. 2016. <http://ianbaldwin. com/wordpress/wp-content/uploads/2012/06/ NGS_2014NeedForChangeinRetailIndustry. pdf $>$.

Behe, B.K., B.L. Campbell, C.R. Hall, H. Khachatryan, J.H. Dennis, and C. Yue. 2013. Consumer preferences for local and sustainable plant production characteristics. HortScience 48:200-208. 
Behe, B.K., B.L. Campbell, H. Khachatryan, C. Hall, J. Dennis, P.T. Huddleston, and R.T. Fernandez. 2014. Incorporating eye tracking technology and conjoint analysis to better understand the green industry consumer. HortScience 49:1550-1557.

Behe, B.K., R. Nelson, S. Barton, C. Hall, C.D. Safley, and S. Turner. 1999. Consumer preferences for geranium flower color, leaf variegation, and price. HortScience 34:740-742.

Boxall, P. and W. Adamowicz. 2002. Understanding heterogeneous preference in random utility model: A latent class approach. Environ. Resour. Econ. 23(4):421-446.

Butterfield, B.W. 2004. National Gardening Association survey 2003. Conducted by Harris Interactive and published by the National Gardening Association, Burlington, VT.

Campbell, B.L., H. Khachatryan, B.K. Behe, J. Dennis, and C.R. Hall. 2014. U.S. and Canadian consumer perception of local and organic. Intl. Food Agribus. Mgt. Rev. 17(2):21-40.

Collart, A.J., M.A. Palma, and C.E. Carpio. 2013. Consumer response to point of purchase advertising for local brands. J. of Agr. Appl. Econ. 45(2):229-242.

Collart, A.J., M.A. Palma, and C.R. Hall. 2010. Branding awareness and willingness-to-pay associated with the Texas Superstar ${ }^{\mathrm{TM}}$ and Earth-Kind ${ }^{\mathrm{TM}}$ brands in Texas. HortScience 45:1226-1231.

Darby, K., M.T. Batte, S. Ernst, and B. Roe. 2008. Decomposing local: A conjoint analysis of locally produced foods. Amer. J. Agr. Econ. 90(2):476-486.

Dekhili, S., L. Sirieix, and E. Cohen. 2011. How consumers choose olive oil: The importance of origin cues. Food Qual. Prefer. 22(8):757-762.

Dennis, J.H. and B.K. Behe. 2007. Evaluating the role of ethnicity on gardening purchases and satisfaction. HortScience 42:262-266.

Food Marketing Institute. 2011. U.S. grocery shopper trends. Food Marketing Institute, Arlington, VA.

Greene, W.H. and D.A. Hensher. 2003. A latent class model for discrete choice analysis: Contrasts with mixed logit. Transportation Res. B 37(8):681-698.

Hall, C.R., B.L. Campbell, B.K. Behe, C. Yue, R.G. Lopez, and J.H. Dennis. 2010. The appeal of biodegradable packaging to floral consumers. HortScience 45:583-591.

Hall, C.R. and M.W. Dickson. 2011. Economic, environmental, and health/well-being benefits associated with green industry products and services: A review. J. Environ. Hort. 29:96-103.
Kafle, A., S. Swallow, and E. Smith. 2014. Does public funding affect preferred tradeoffs and crowd-in or crowd-out willingness to pay? A watershed management case. Environ. Resour. Econ. 60:471-495.

Khachatryan, H. and A. Rihn. 2015. Floridian consumer perceptions of local versus organic ornamental plants. University of Florida Institute of Food and Agricultural Sciences Extension FE964. 1 May 2016. <https://edis.ifas. ufl.edu/pdffiles/FE/FE96400.pdf>.

Kuhfeld, W.F. 2010. The macros. In: Marketing research methods in SAS. Technical Paper MR-2010. SAS Institute Inc., Cary, NC. 10 Jan. 2016. <https://support.sas.com/techsup/ technote/mr2010title.pdf $>$.

Lim, K.H., W. Hu, L.J. Maynard, and E. Goddard. 2013. U.S. consumers' preference and willingness to pay for country-of-origin-labeled beef steak and food safety enhancements. Can. J. Agr. Econ. 61(1):93-118.

Lopez, R.N., Plesha, and B. Campbell. 2015. Northeast economic engine: Agriculture, forest products, and commercial fishing. Farm Credit East. 18 Jan. 2016. <http://www.zwickcenter. uconn.edu/outreach_reports_10_1981703122. pdf>.

Low, S.A., A. Adalja, E. Beaulieu, N. Key, S. Martinez, A. Melton, A. Perez, K. Ralston, H. Stewart, S. Suttles, S. Vogel, and B. Jablonski. 2015. Trends in U.S. local and regional food systems. U.S. Department of Agriculture, Economic Research Service, AP-068. 21 Jan. 2016. $<$ http://www.ers.usda.gov/media/1763057/ ap068.pdf $>$.

Low, S.A. and S. Vogel. 2011. Direct and intermediated marketing of local foods in the United States. U.S. Department of Agriculture, Economic Research Service, Report no. 128. 21 Jan. 2016. <http://www.ers.usda.gov/publications/erreconomic-researchreport/err128.aspx>.

Martinez, M., M. Hand, M. Da Pra, S. Pollack, K. Ralston, T. Smith, S. Vogel, S. Clark, L. Lohr, S. Low, and C. Newman. 2010. Local food systems: Concepts, impacts, and issues. U.S. Department of Agriculture, Economic Research Service, ERR-97. 21 Jan. 2016. <https:// books.google.com/books?id=wVTjlY75WW8C\& printsec $=$ frontcover\&source $=$ gbs_ge_summary $\mathrm{r} \&$ cad $=0 \# \mathrm{v}=$ onepage $\& \mathrm{q} \& \mathrm{f}=$ false $>$.

Onozaka, Y. and D.T. McFadden. 2011. Does local labeling complement or compete with other sustainable labels? A conjoint analysis of direct and joint values for fresh produce claims. Amer. J. Agr. Econ. 93(3):693-706.
Onozaka, Y., G. Nurse, and D.D. Thilmany. 2010. Local food consumers: How motivations and perceptions translate to buying behavior. Choices (N.Y. N.Y.) 25(1).

Palma, M.A., Y. Chen, C. Hall, D. Bessler, and D. Leatham. 2010. Consumer preferences for potted orchids in the Hawaiian market. HortScience 20:239-244.

Racine, E.F., E.A. Mumford, S.B. Laditka, and A.E. Lowe. 2013. Understanding characteristics of families who buy local produce. J. Nutr. Educ. Behav. 45(1):30-38.

Rihn, A., H. Khachatryan, B. Campbell, C. Hall, and B. Behe. 2015. Consumer response to novel indoor foliage plant attributes: Evidence from a conjoint experiment and gaze analysis. HortScience 50:1524-1530.

Safley, C.D. and M.K. Wohlgenant. 1995. Factors influencing consumers selection of garden centers. J. Agribusiness 13(1):33-50.

Satterthwaite, L.N., J.J. Haydu, and A.W. Hodges. 2006. Consumer purchasing habits of environmental horticulture products in Florida. J. Environ. Hort. 24(2):68-73.

Sturdivant, B. 2013. Is your greenhouse profitable? GrowerTalks. 14 Jan. 2016. <http://ballpublishing. com/GrowerTalks/ViewArticle.aspx?articleid= 20496>.

U.S. Census Bureau. 2011. State and county quickfacts: Connecticut. 24 Jan. 2016. <http:// quickfacts.census.gov/qfd/states/09000.html >.

U.S. Census Bureau. 2015. Census Bureau releases 2010 census demographic profiles for Alaska, Arizona, California, Connecticut, Georgia, Idaho, Minnesota, Montana, New Hampshire, New York, Ohio, Puerto Rico and Wisconsin. 24 Jan. 2016. <https://www.census.gov/newsroom/ releases/archives/2010_census/cb11-cn137. html>.

Wedel, M. and W.A. Kamakura. 2000. Market segmentation: Concepts and methodological foundations. Kluwer Academic Publishers, Boston, MA.

Yue, C. and B.K. Behe. 2008. Estimating U.S. consumers' choice of floral retail outlets. HortScience 43:764-769.

Yue, C., J.H. Dennis, B.K. Behe, C.R. Hall, B.L. Campbell, and R.G. Lopez. 2011. Investigating consumer preference for organic, local, or sustainable plants. HortScience 46:610-615.

Yue, C. and C. Tong. 2009. Organic or local? Investigating consumer preference for fresh produce using a choice experiment with real economic incentives. HortScience 44:366371. 